\title{
Migration and Remittances: A Strategic Tool for Socio-economic Development in Ikpoba-Okha LGA, Southern Nigeria
}

\author{
Alenkhe Odianonsen Augustine \\ Longe Joshua Sunday \\ Department of Sociology \& Anthropology, University of Benin \\ princealenkhe@gmail.com \& joshua.longe@uniben.edu
}

Doi:10.5901/jesr.2015.v5n2p29

\begin{abstract}
For reasons which border on the search for greener pastures and survival, man has been a migratory species since the earliest of times. Underlying all patterns of migration is the basic search for systematic reward, material and non-material to their homeland. This paper discusses the issue of international migration and its impact on the point of origin of migrants. Two theoretical approaches, the Todaro migration model and the Functionalist model, are considered in our analysis of 450 Nigerian migrants' families in two communities in Ikpoba-Okha Local Government area of Edo State with money and the values of goods as referents. Our findings show that although home remittances do not have a uniform impact on the communities and families of migrants, they are however significant and appreciated. There appears to be an emerging pattern of family solidarity and communal expectations from migrants who may be said to be living up the challenge. We conclude that there is an emerging relationships arising from the impact of home remittances from Nigerian migrants in Europe.
\end{abstract}

Keywords: Development, Families, Migration, Remittance,

\section{Introduction}

From the Darwinian thesis on evolution of species to his Adamic origin through creation, man has continued to move from one place to another. Right from the Palaeolithic era of hunting and gathering up to the present era of globalization and social-networking, man has not relented in moving. Even so, different each epoch has its own pattern and type of movement unique and dominant to it. For example, in hunting and gathering societies, it was mainly in search of food and security (Brumer, 2008). Gradually, it changed from search for food and security to the modern era which was inaugurated by the forceful confiscation of able bodied men from their own land to be used as slave in plantations in Europe and the new world. In pre-colonial Africa, movement was largely forceful especially during slave trade era, a feature that has endured into the postcolonial era. A more significant characteristic of migration in the postcolonial period is the push factor of worsening national poverty manifested by unemployment and the growing spectre of the poorfare state. In sharp contrast to Africa's flagging economies is the pull factor of economic el dorado and lure of good life in Europe and America. Thus migrants from most developing countries are forcing their way out of drudgery at home for better life in the developed countries of the world. This new wave of migration involves all segments of society. It is not selective sex, age, education or religion and it transcends the dominant pattern of internal migration, that is, rural to urban migration which has itself thrown up the dilemma of overurbanization in virtually all Third World countries.

As pointed out by Adepoju (2008), unemployment in Africa urban area is usually associated with the youth. In the 1960s, the pool of unemployment was localized among primary school leavers, but now the pool is constituted by graduates from tertiary educational institutions and school drop-outs causing an amplified effect of the unemployment situation. He further asserted that unemployment has so adversely affected the socio-economic situation that the most viable option available is for the unemployed to use the available resource in their disposal to move for a greener pasture abroad. For a few of these migrants, this movement promises upward socio-economic mobility, while for others it is basically a matter of survival. Nigeria is one of the countries of the world with a massive challenge of unemployment and a marked rural-urban dichotomy. Although the nation is generally characterized by inadequate and poor social and economic infrastructure, rural communities are disproportionately more disadvantaged than urban centres. This is a function a faulty development approach marked by governmental neglect and an unjustifiable urban bias. Consequently, the number of rural inhabitants that migrate to cities with high hopes of overcoming the socio-economic powerlessness 
consistent with rural life is unprecedented (Nwokocha, 2007). Nigeria is perceived as a rural state, and this implies that most of her citizens are rural dwellers. As a result, many of her citizens, in looking for greener pastures tend to migrate from the rural areas to urban settlements where they hope to live a fairly comfortable life and also help the loved ones they left behind in the rural sector. It has been further observed that in Africa and other part of the developing world, Kerina (2011) a majority of the migrants, especially young girls and women, are literarily forced to migrate to the urban area in search of employment mostly as house-help (Kerina, 2011). More recently, Edo State has become notable as a point of origin for Europe-bound Nigeria migrants. This study examines to what extent these migrants have, through remittances, brought any benefit or succour to the society in general and families of the migrants in particular.

\section{Migration and Remittances}

Migration is a universal phenomenon which often takes the form rural-to-rural, rural-to-urban, urban-to-rural and urban-tourban movements. In Nigeria as in most other poor nations, the most prominent pattern of migration is the rural-urban migration. This is because the poor countries of the world are more of rural than urban states. Does this suggest an inherent quality in rurality that conduces poverty? We do not think so but it is apparent that poverty may be more readily take root in the rural rather than the urban sector because of the smaller scale of the economy of the former. Since independence, Nigerian migration has often been associated with the issues raised by rapid urbanization, political unrest, ethnic conflicts and fragmentation of rural families and communities (Anand and Kombi, 2010). In addition to massive internal migration, Nigeria also represents one of the more mobile societies in Africa in terms of across-the-border migration. Populations moving from Nigeria to East, West, and Southern Africa, as well as Europe and North America, constitute a notable and vibrant diaspora leaving the country with strong family ties across all continents. For example, according to the United Nations, there are approximately 1.1 million Nigerians living outside their home country, representing 0.84 percent of the Nigerian population. But this figure woefully falls short of the reality because just in West Africa, the trend of Nigerian migration is substantial with Ghana alone accounting for at least half a million Nigerians (Orozco, 2006).

Home remittance is a logical follow-up to migration. African migrants rarely move for individual benefits of better life and conducive environments at their destinations. Rather African migration is conceptualized as an effort to improve family, not individual life. Thus at the earliest opportunity migrants send money and other valuables and household items home. Even though the risks associated with migration may be well known, the migrant tends not to be deterred because of the prospects of remittance. Migration may then be seen as a risk management strategy due to the potential benefits that may accrue. Remittance flows represent any monetary and/or in-kind transfers that migrants send home to family members or other beneficiaries either through formal or informal channels (World Bank, 2005). These remittances are usually of greater importance to family members back home than to the migrants themselves at their new abode. As migrants continue to strive for better life, there is a concomitant increase in the expectancy of the returns they are to send home. Such expectation is a function of pressure from home and a psychological disposition by which migrants take home remittance as a duty. With remittances becoming an important source of livelihood among households, international migration has been on the increase in recent times.

Remittances constitute one of the largest financial inflows to many transitional and developing economies and this form of financial inflows exceeds international aid in some instances. Ozden and Schiff (2006) suggested that migrant remittances to their place of origin have been identified as the second largest form of capital inflow into Africa after Foreign Direct Investments (FDI) and are much larger than Overseas Development Assistance (ODA). According to Ratha and Page (2003), the flow of international remittances to developing countries in 2002 stood at $\$ 72$ billion, a figure which was much higher than the total official aid flow to the developing world for that year. And as noted in the Migration and Remittances Report Factbook 2011, Nigeria in 2009 received billions in remittance from citizens living in the diaspora, a fact corroborated by Guptal et. al.(2009) who asserted that remittances to Nigeria was estimated at $\$ 10$ billion in 2009, making the country the highest receiver in Sub-Saharan Africa and one of the top 25 recipients in the World. One year later, the country moved into the top 10 list of remittance-recipient countries. As the report further notes, the average Nigerian doctor living in the United States sent foreign currency running into hundreds of dollars back home. The official data for the months of January-August 2010 indicate that the Central Bank of Nigeria (CBN) supplied approximately 27.1 percent of the $\$ 52$ billion of inflows to Nigeria's foreign exchange market, with "autonomous sources", oil companies, international institutions, and remittances accounting for the rest. Official CBN figures also show that inflow of remittances increased tremendously from $\$ 2.3$ billion to $\$ 17.95$ billion in the 2004-2007 period. Further, Guptal et al. reported that the volume of remittances to developing countries has been growing significantly on the average of 16 
per cent annually since 2000 .

\section{Remittances and Societal Development}

Development is about incremental and cumulative progress in various aspects of life: socio-cultural, moral, religious, intellectual, spiritual, political, economic and technological. It refers to progressive unfolding of the inner potentialities of a given reality. As it applies to a people, development is the integration of various activities of a people towards fulfilling the goal of better living in all its ramifications (Nzemeka and Erhagbe, 2002). By sending remittances, migrants directly participate in the development process. Remittances are used not only for the upkeep of the family but also in all developmental projects which may transcend the benefits of the immediate family. A recent study by Oseni and Winter (2009), using a nationally representative dataset, showed that about 5.5 per cent of the average household income in Nigeria is from remittances, and that households in the southern regions received more from remittances than their northern counterpart. INSTRAW (2008), in a study on gender, remittances and development in the Philippines found that remittances contribute to improvement in food security of receiving households. Besides, the study also found a significant change in food consumption patterns - leading to increased consumption of quality foods and food away from home. Apart from the direct nutrition effects found by this study, some evidence of indirect effects on non-receiving households has been reported. Remittances have aided societal development in no small measures both socially, politically and economically.

Remittances are considered an important and stable source of income for households in many countries because it is least affected by economic downturns and remains a stable source of family income and they have indeed transformed the way of life in many societies. Alfieri et.al (2005) concluded form their study that there has been transformation from the traditional ways to a more modern system of operation as they (migrants) usually bring foreign culture and style to their home of origin. These remittances have contributed to modernization and socio-economic development in many villages through the introduction of modern equipment, such as of mobile telephones, sophisticated household machines like microwave stoves, washing machines, satellite and cables television receivers, computers and other recent technological innovations.

If as the Central Bank of Nigeria (CBN) has shown, the inflow of remittances marginally declined in 2008, they nevertheless still played a significant role in poverty alleviation at household level in 2009 during the economic crisis (Central Bank of Nigeria, 2007a). Also a 2005 World Bank study found that remittance recipients are located predominantly in Nigeria's southeast and southwest regions where proceeds are used mainly in general family expenses, social security for the elderly, the disabled and orphans. Other areas of expenditure include education of relatives, repayment of loans taken to sponsor migration, business development and financing of already existing businesses, special occasions like funerals, weddings, pilgrimages and festival such as New Yam (among the lgbo in south-eastern Nigeria), Igue (among the Bini in Edo State) and Christmas and New Year. Remittances are also used in meeting family contributions to communal development projects in social and economic infrastructure.

\section{Theoretical Approaches}

Two theoretical perspectives may be adopted in the study of migration, remittances and benefits to society, the HarrisTodaro model and functionalist approach.

\subsection{The Harris-Todaro Migration Model}

The Harris-Todaro model is an economic model used in development and welfare economics to explain some of the issues in rural-urban migration. Its basic assumption is that migration decision is more of a function of expected income differentials between rural and urban areas rather than just wage differentials. This implies that rural-urban migration, in a context of high urban unemployment can be economically rational if expected urban income exceeds expected rural income.

Based on the rationality in choice, it is assumed that the greater the urban income the greater the chance of people migrating to the urban area. Using the Harris-Todaro model of migration, it can be deduced that rural-urban migration is mainly an economic action taken as a result of wage differences in industrial and agricultural sectors. Ruralurban migrants are therefore rational migrants as cost-benefit analysis largely determines the decision to migrate. Going by the Harris-Todaro model, migration becomes a thought through process of event that often occur after a thorough 
analysis of the chances available before the movement into a better environment of the urban area. Migration is thus a function of remittance, the latter determining the former. In other words, migrants take the decision to move only if prior analysis of the conditions of the host environment favours a favourable decision. Contrariwise, if the analysis results in a negative conception of the city and the prospects of remittance are nugatory, then the decision to migrate will not be taken.

\subsection{Functionalism}

Functionalism, especially structural-functionalism, conceives of a society as an organism and compares societal development to the evolution of an organism. It explains the social system as that in which every element or unit of the structure fit together harmoniously on the basis value consensus. The basic assumption is that of functional unity between the work of the individual unit and the entire system with the former working for the latter. This theory views society as a system, that is, as a set of interconnected parts that work together harmoniously for the survival of the whole. If the social system or society is to survive, every institution must function compositely to survive. Institutions are better understood only in reference to their contribution to the system.

Against this background, the migrant is conceptualized as that individual whose exit affects the socio-demographic structure of the society positively. The departure is for the betterment of the family and society, a goal achieved through remittance which is viewed from the angle of the beneficiary, as assistance to the family and society. Remittances are therefore functional both in the manifest and latent forms. Manifest functions of remittances include payment of bills, financial support to the family, etc. On the other hand latent functions refer to increased social, economic and health status of the family at home.

\section{Method and Materials}

The study was conducted in Oregbenin and Uteh Ne'rekpokin communities in Ikpoba-Okha Local Government Area (LGA) of Edo State, southern Nigeria and primary data were collected using both qualitative and quantitative methods. Through a combination of cluster and simple random sampling procedures, we reached a total sample size of 450 households.

The study population comprised of families of migrants. Edo State has in recent times become a notable point of origin of emigrants to Europe and it is a popular belief that most of these migrants are women whose movements may not have been voluntary. Respondents are predominantly of the Bini ethnic stock, perhaps the largest group in Edo State. The other notable ethnic groups in Edo State include Esan, Etsako, Owan and Akoko Edo. Data gathering began in February and ended in May 2013.

\section{Results and Discussion}

Table 1. Home remittances in the last one year

\begin{tabular}{|c|c|c|c|c|c|c|}
\hline \multicolumn{7}{|c|}{ Has the migrant ever sent anything home since the past one year? } \\
\hline Yes (392) & $(58)$ & & & & & \\
\hline $87.1 \%$ & $12.9 \%$ & & & & & \\
\hline \multicolumn{7}{|c|}{ If yes, what items has been sent home mostly since the past one year. } \\
\hline $\begin{array}{l}\text { Clothes, shoes etc. } \\
\text { (41) }\end{array}$ & $\begin{array}{l}\text { Electronics. } \\
\text { (18) }\end{array}$ & $\begin{array}{l}\text { Laptops. } \\
\text { (19) }\end{array}$ & $\begin{array}{l}\text { Cash. } \\
(110)\end{array}$ & $\begin{array}{l}\text { Cars. } \\
\text { (4) }\end{array}$ & $\begin{array}{l}\text { Virtually all listed. } \\
(200)\end{array}$ & $\begin{array}{l}\text { Total } \\
\text { (392) }\end{array}$ \\
\hline $10.4 \%$ & $4.5 \%$ & $4.8 \%$ & $28.1 \%$ & $1.2 \%$ & $51.0 \%$ & 100 \\
\hline
\end{tabular}

Source: Fieldwork 2013.

Table 1 shows that over 87 per cent of all migrants' families have received remittances in the year preceding our study and most of these remittances were in form of cash. Other remitted items include house items and consumer goods including clothes and shoes, cars, electronics, computers and telephone sets, etc. It is noteworthy that 51.0 per cent of respondents actually received and assortment of items from migrants. Therefore while it is obvious that cash remittances are preferred, migrants avail themselves of any opportunity to add value at home by sending virtually anything they may fancy. Non-cash remittances are most visibly second-hand or used items which may have been acquired very cheaply in Europe. 
Table 2. Home remittances intervals and development

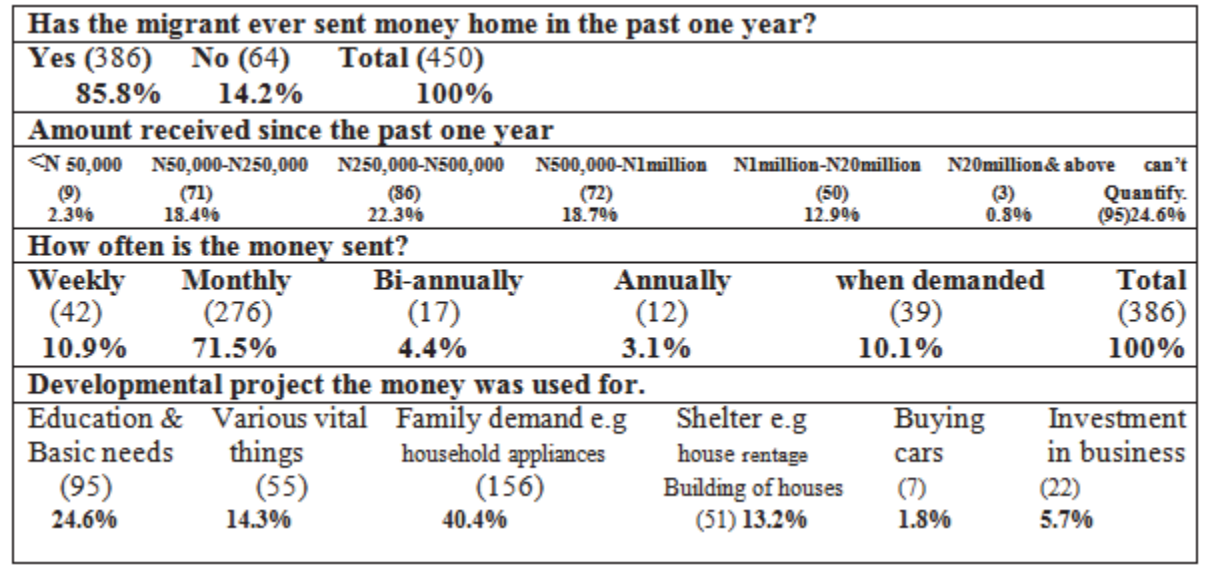

Sources: fieldwork 2013

From our data in Table 2, it is obvious that cash remittances to our communities are quite substantial as most receipts are in excess of the per capita income. Cash receipts range from $\$ 300$ ( $\$ 1=N 150$ ) to over $\$ 200,000$. Remittances may be received as often as every week but the majority (71.5 per cent) claimed they got receipts monthly. Although remittances may be quite tasking for senders, expectations are always high at home. Thus in spite of regular remittances, over 10 per cent of respondents actually made additional demands for cash especially in times of family emergencies like sudden illnesses, communal crises, deaths or similar calamity. Going by pattern of home remittances in Oregbenin and Uteh Ne'rekpokin communities, it would appear that official figures released by CBN and the World Bank may be well below reality. Note also that 24.6 per cent of respondents could not quantify receipts. There is therefore an invisible component of home remittances which may themselves be quite substantial. According to one respondent whose sister regularly sends money from Spain:

I can't quantify the money sent to me by my sister because I go to Erie (a local bureau de change) whenever she sends money. I change the money immediately but you know the value of the naira is never steady, always rising and falling every time, so giving you a precise amount of how much she has sent is like lying. On that ground I cannot quantify the money sent to in the past one year

On the utilization of these remittances, result shows that majority of the respondents used their money for familyrelated challenges and purchase of sundry home utility items. These include repairs, debt servicing, various ceremonies, utensils and appliances. Another family related item of expenditure is education. Because high value is placed on education, respondents spend huge sums of money sent from abroad in training their wards in private primary and secondary schools as well as universities. It is well known in Nigeria that most public schools especially at the primary and secondary levels are avoided by just anybody who can afford to pay for private schools.

\section{Conclusion}

Migration and remittances have a strong, significant impact on the socio-economic development on the family in particular and society in general like in Ikpoba-Okha, it has uplifted the socio-economic level of the people as several household members have benefited immensely from the remittances received. This is a clear indication that remittances are responsible for some of the evolutionary changes in Ikpoba-Okha, not only on the satisfying of the basic needs which include food, clothing, housing and education but also touching the socio-economic life of the people, by transforming many families from tenant-hood to house owner, making many unemployed to be business owners by virtue of the money received, etc. 


\section{Recommendation}

The study identifies migration and remittances as strong tools for development at both family and societal level. The effects of both variables cannot be isolated from the wider environment in which they occur. Hence, the recommendations this study present takes into cognizance the wider society.

Remittances, being one of the major sources of revenue to the country through her citizen outside the country, should be properly maximized for the benefits of the Nigerian society. To do this end, the government should identify all Nigerian citizens abroad; liaise with them, identify the exact amount of money sent yearly as remittances with a view of synergizing to establish viable enterprises and job opportunities in the country. This will enable the government to annex all the resources sent by these citizens for proper usage by the beneficiaries. It is believed that if this is effectively utilized, it will enable the country in the achievement of one of the MDGS, which is to reduce poverty through provision of employment. This partnership will ultimately lead to employment generation. The government should also create a forum where her citizens in diaspora especially the professionals can discuss and exchange ideas that is development centred.

\section{References}

Adepoju, A. (2008). International migration in and from Africa: Dimensions, Challenges and Prospects. Population, Human, Resources and Development in Africa (PHRDA). Afolayan, A.A. Ed. Dakar:

Alfieri, A., Havinga, I., and Hvidsten, V. (2005). Definition of Remittances and Relevant BPM5 Flows. United Nations Department of Economic and Social Affairs Statistics Division, Meeting of the Technical Subgroup on Movement of Natural Persons - Mode 4 Paris,

Anand Singh and Kombi Sausi (2010). Voluntary Associations and Remittances among Nigerian Migrants Living in Central Durban. International journal of sociology. J Sociology Soc Anth, 1 (1-2): 59-70 (2010)

Brumer, A. 2008. Gender relations in family- farm agriculture and rural- urban migration in Brazil. Latin America perspectives 35(6): Pg11-28. Retrieved on 15/4/2011 from http/www.sagepub.com/content/35/6/11.full.pdf

Central Bank of Nigeria (CBN) 2007a The Remittance Environment in Nigeria. Unpublished report of a study by the Research and Statistics Department, Abuja.

Central Bank of Nigeria (CBN) 2007b Annual Report and Statement of Accounts for the Year Ended 31st December, 2006. Macroeconomic indicators (2002-2007), Abuja

Goldschmidt, Walter R.(1966), Comparative Functionalism. Berkley and Los Angeles, CA: University of California Press

Gupta, S.; Pattillo, C.A. and Wagh, S. (2009). Effect of remittances on poverty and financial development in Sub-Saharan Africa. World Development, 37(1): 104-115.Development Studies.

INSTRAW (2008): Gender, remittances and development: The case of Filippino migration to Italy. United Nations International Research and Training Institute for the Advancement of Women (UN-INSTRAW), Santo Domingo, Dominican Republic.

Kerina K. H. 2011. "Migration and Remittances: A theoretical perspective" in an international journal of current research, vol 3, issue, 6, pp 411-417

Migration and Remittances Factbook 2011, p. 18.

Nwokocha, E.E. (2007). Gender Inequality and Development in Nigeria: a Review on Antithesis. South-South Journal of Culture and Development. Forthcoming.

Nzemeka A.D,and Erhagbe E.O, (2002) Nigeria People and Culture (2nd Edition). Mindex Publishing Company Limited. Edo State, Nigeria.

Orozco, Manuel. (2006). "West African Financial Flows and Opportunities for People and Small Businesses." Report prepared for the United States Agency for International Development, March.

Oseni, G. and Winters, P. (2009): Rural nonfarm activities and agricultural crop production in Nigeria. Agricultural Economics, 40(2), 189-201.

Ozden, Caglarr \& Maurice Schiff (eds.). (2006). International Migration, Remittances and the Brain Drain, New York: World Bank/ Palgrave Macmillan.

Harris, J and Todaro, M. (http://en.wikipedia.org/wiki/Harris\%E2\%80\%93Todaro_model)

Ratha. H. A \& Page, J. (2003). The Impact of International Migration and Remittances on Poverty. Poverty Reduction Group. W.B. Paper Prepared for DFID/World Bank Conference on Migrant Remittances, London, October 9-10, 2003.

World Bank 2005. Global Economic Prospects 2006. Economic Implications of Remittances and Migration. Washington: World Bank. 